\title{
Childhood nutrition and poverty
}

\author{
Michael Nelson \\ Department of Nutrition and Dietetics, King's College London, 150 Stamford Street, London SE1 8WA, UK
}

\begin{abstract}
One in three children in Britain lives in poverty (households whose income was less than $50 \%$ average earnings). Low income is associated with poor nutrition at all stages of life, from lower rates of breast-feeding to higher intakes of saturated fatty acids and lower intakes of antioxidant nutrients. Moreover, there is increasing evidence that poor nutrition in childhood is associated with both short-term and long-term adverse consequences such as poorer immune status, higher caries rates and poorer cognitive function and learning ability. These problems arise primarily because parents do not have enough money to spend on food, not because money is being spent unwisely. Policy options to improve the dietary health of poor children include: giving more money to the parents by increasing Income Support (social security) payments, providing food stamps or vouchers, and using food budget standards to inform the levels of income needed to purchase an adequate diet; feeding children directly at school (not only at lunchtime but also at breakfast or homework clubs), by providing free fruit at school, and by increasing entitlement to free food amongst children living in households with low incomes; improving access to a healthy and affordable diet by first identifying 'food deserts' and then considering with retailers and local planners how best to provide food in an economical and sustainable way. The value of using food budget standards is illustrated with data relating expenditure on food to growth in children from 'at-risk' families (on low income, overcrowded, headed by a lone parent or with four or more children under 16 years of age) living in a poor area in London. Lower levels of expenditure are strongly associated with poorer growth and health, independent of factors such as birth weight, mother's height, or risk score. The present paper provides evidence that supports the need to review Government legislation in light of nutrition-related inequalities in the health of children.
\end{abstract}

Childhood: Poverty: Food budget standards: UK food policy options

One in three children in Britain lives in poverty. This is not a melodramatic statistic conjured up for political capital; it is a published government statistic based on the number of children living in households whose income is less than half average earnings. A good number of these children live in lone-parent households. Indeed, $59 \%$ of lone parents live in poverty, the great majority of whom are on Income Support (Government Statistical Service, 1996). However, $23 \%$ of households with two parents also live in poverty, and many households are in employment and in poverty. It is inevitable that poverty which is so widespread will have adverse consequences on the growth and health of children in Britain. The purpose of the present paper is to establish the scale of nutritional poverty, examine some of the consequences, and consider some of the policy options which have the potential to alleviate part of the problem. The problems of children living in developing countries will not be considered in the present paper.

\section{The scale of the problem}

In 1979, five million individuals in England and Wales (9\% of the population) lived in households whose income was less than $50 \%$ of the average earnings. By 1994, this number had increased to 13.7 million individuals, or $24 \%$ of the population. Of these 13.7 million, 4.2 million (32\% of children living in England and Wales) were dependent children under the age of 16 years; i.e. one-third of children in England and Wales are living in poverty (Dennehy et al. 1997).

In social class IV, $6.5 \%$ of children are born under 2500 g compared with $5 \%$ in social class I. Stillbirth rates in social class $\mathrm{V}$ are almost twice the rates in social class I (7.9 v. 4.6 stillbirths per 1000 births (live and still)). Similar differentials exist for other measures of maternal and infant health (Dallison \& Lobstein, 1995).

The problem is also reflected in patient consulting ratios. Average consulting rates for children aged $0-15$ years living

Abbreviation: LCA, low cost but acceptable.

Corresponding author: Dr Michael Nelson, fax + 44 (0)20 7848 4185, email michael.nelson@kcl.ac.uk 
in England and Wales are typically 20-25\% lower in social classes I + II than in social classes IV + V for infectious and digestive diseases, and $35 \%$ lower in girls for endocrine and nutrition-related disorders (including insulin-dependent diabetes mellitus and obesity). The patient consulting ratios for pregnancy in girls aged 10-15 years (if rates for England and Wales as a whole are set to equal 100) are 53 for social Classes I + II and 135 for social classes IV + V (Dennehy et al. 1997).

These gulfs in health indicators between rich and poor are indicative of problems which persist from one generation to the next. The present paper will go on to show that socialclass differences in nutrition in childhood are in part to blame for these health differentials, mediated through both short-term and long-term consequences. It goes on to suggest policy options which can address these problems.

\section{Diet and health in the first two decades of life}

\section{Infants}

Breast-feeding in children from social class I is $90 \%$ at birth, falling to $73 \%$ at 6 weeks and $42 \%$ at 6 months. In contrast, breast-feeding rates in social class V start at $50 \%$ at birth, fall rapidly to $23 \%$ at 6 weeks, and have dropped to only $11 \%$ at 6 months.

Two reports in the last decade on infant feeding and weaning practices (Martin \& White, 1988; Mills \& Tyler, 1992) show that infants from lower social classes or lower income groups have a higher consumption of infant formulas, potatoes, biscuits, confectionery, squashes and soft drinks, and a lower consumption of breast milk, cow's milk and milk products, and fruit (Table 1). This pattern of consumption is reflected in nutrient intakes, which are higher in saturated fatty acids and dietary cholesterol, and lower in carotene and vitamin $\mathrm{C}$.

There is now ample evidence to show that breast-feeding is protective against infection in early life, enhances gut development and may protect against insulin-dependent diabetes mellitus, allergy and eczema (James et al. 1997). Lucas et al. (1992) have shown that in children who were born preterm intelligence quotient at age 7.5 years is significantly (eight points) higher in those children who were given breast milk than in those who were given infant formula. While this finding does not necessarily extrapolate to children not born preterm, there are reasonable physiological arguments to suggest that part of the observed differences in intelligence quotient between social classes may be related in part to infant feeding practices.

\section{Toddlers}

The report by Gregory et al. (1995) on the diets of toddlers aged 1.5-4.5 years shows clear differences in consumption patterns between children from non-manual $v$. manual social classes, or between children from families receiving benefits compared with those not receiving benefits. The differences are summarized in Table 1, which shows that toddlers from lower social class or poorer families are more likely to have foods lower in dietary fibre (e.g. white bread and low-fibre breakfast cereals), higher in fats (e.g. fried chicken, burgers and kebabs, meat pies and pastries, and chips and crisps), and higher in sugar. They tend to have lower consumption of pizza, higher-fibre foods (including fruit and vegetables), and carcass meat and poultry (not fried). They also have lower consumption of infant formulas and commercial infant drinks (due to earlier weaning). The net result is higher consumption of sugar, starch and $\mathrm{Na}$ (present in higher amounts in processed foods which are more commonly consumed), and lower intakes of dietary fibre, $\beta$-carotene equivalents, vitamin $\mathrm{C}, \mathrm{Fe}, \mathrm{Ca}$ and $\mathrm{I}$. The most obvious health consequences are higher rates of caries and slower recovery from infection (James et al. 1997). Higher sweet consumption is associated with lack of variety in the diet and slower development of more varied diet later in childhood. There is also some evidence that lower intakes of antioxidants and $\mathrm{Zn}$ may be associated with higher risk of asthma (Burney, 1995).

\section{Schoolchildren}

The best evidence currently available regarding social-class differences in food consumption of schoolchildren is based on the 1983 survey of a national sample (Department of Health, 1989), although newer data is soon to be published based on the 1997-8 National Diet and Nutritional Survey of 5-18 year olds. The older data shows that in children from lower social classes (and from families who receive benefits or with unemployed fathers) consumption was higher for bread (particularly white bread), eggs, potato, chips, baked beans and sugar, and lower for milk, carcass meat, chicken and fruit (Table 1). Nutrient intakes were consequently lower for $\beta$-carotene equivalents and vitamin C. Other survey data (Dowler \& Calvert, 1995; Ruxton \& Kirk, 1996) suggest that children of families from lower social classes have lower intakes of $\mathrm{Fe}, \mathrm{Ca}$, folate and other nutrients.

The health consequences include higher excretion rates of the lipid peroxidation product malondialdehyde (which might be associated with higher rates of oxidative damage of DNA; James et al. 1997). M Nelson and R Ash (unpublished results) have observed higher rates of anaemia amongst adolescent girls from unemployed families, and lower intelligence quotients associated with lower haemoglobin levels $(r 0.24, P=0.003)$ and higher serum transferrin receptor values $(r-0.24, P=0.003)$. Nelson et al. (1994) suggest that the lower Fe status is likely to be associated with reduced activity levels and lower bone mineral density (and consequently lower peak bone mass in adulthood). If the poorer Fe status in adolescence persists into pregnancy, it will be associated with higher risks of stillbirth and low birth weight, and increased risks of hypertension and heart disease in the offspring in adulthood (Barker, 1997).

\section{National Food Survey data}

The National Food Survey reports estimates of food availability and nutrient intake based on $7 \mathrm{~d}$ records of food purchases according to household composition and income. It is thus possible to compare data between income groups for a given family size. Fig. 1, for example, shows the levels of food acquisition (excluding foods purchased and eaten 
Table 1. Dietary characteristics of British children by socio-economic group (SEG)

\begin{tabular}{|c|c|c|c|c|}
\hline Data source & Reference & Comparison & Higher in low SEG & Lower in low SEG \\
\hline \multirow[t]{2}{*}{$\begin{array}{l}\text { Infants }(0-12 \\
\text { months })\end{array}$} & \multirow[t]{2}{*}{$\begin{array}{l}\text { Martin \& White (1988) } \\
\text { Mills \& Tyler (1992) }\end{array}$} & \multirow[t]{2}{*}{$\begin{array}{l}\text { I v. IV + V } \\
A, B, C 1 v . C 2, D, E\end{array}$} & $\begin{array}{l}\text { Foods: } \\
\text { Infant formulas } \\
\text { Potatoes } \\
\text { Biscuits } \\
\text { Confectionery } \\
\text { Squashes and soft drinks }\end{array}$ & $\begin{array}{l}\text { Foods: } \\
\text { Breast milk } \\
\text { Cow's milk and milk products } \\
\text { Fruit }\end{array}$ \\
\hline & & & $\begin{array}{l}\text { Nutrients: } \\
\text { Saturated fatty acids } \\
\text { Dietary cholesterol }\end{array}$ & $\begin{array}{l}\text { Nutrients: } \\
\text { Carotene } \\
\text { Vitamin C }\end{array}$ \\
\hline \multirow[t]{2}{*}{$\begin{array}{l}\text { Toddlers } \\
\qquad(1.5-4.5 \text { years })\end{array}$} & \multirow[t]{2}{*}{ Gregory et al. (1995) } & \multirow[t]{2}{*}{$\begin{array}{l}\text { Non-manual } v \text {. manual } \\
\text { Benefits } v \text {. no benefits }\end{array}$} & $\begin{array}{l}\text { Foods: } \\
\text { White bread } \\
\text { Breakfast cereal (low NSP) } \\
\text { Milk puddings } \\
\text { Skimmed milk } \\
\text { Margarine (non-PUFA) } \\
\text { Coated chicken } \\
\text { Burgers and kebabs } \\
\text { Meat pies and pastries } \\
\text { Chips and crisps } \\
\text { Sugar } \\
\text { Chocolate and confectionery } \\
\text { Soft and alcoholic beverages } \\
\text { Tea and coffee }\end{array}$ & $\begin{array}{l}\text { Foods: } \\
\text { Pizza } \\
\text { Wholewheat or soft grain bread } \\
\text { Biscuits and fruit pies } \\
\text { Sponge puddings } \\
\text { Semi-skimmed milk } \\
\text { Infant formula } \\
\text { Cottage cheese } \\
\text { Lamb, chicken, turkey, liver } \\
\text { Raw and salad vegetables } \\
\text { Fresh vegetables } \\
\text { Fruit } \\
\text { Fruit juice } \\
\text { Commercial infant drinks }\end{array}$ \\
\hline & & & $\begin{array}{l}\text { Nutrients: } \\
\text { Energy (lone parent children) } \\
\text { Non-milk extrinsic sugar } \\
\text { Starch } \\
\mathrm{Na}\end{array}$ & $\begin{array}{l}\text { Nutrients: } \\
\text { NSP } \\
\beta \text {-Carotene equivalents } \\
\text { Vitamin C } \\
\text { Fe } \\
\mathrm{Ca} \\
\text { I }\end{array}$ \\
\hline \multirow[t]{2}{*}{$\begin{array}{l}\text { Schoolchildren } \\
\quad(10-15 \text { years })\end{array}$} & \multirow[t]{2}{*}{$\begin{array}{l}\text { Wenlock et al. (1986) } \\
\text { Department of Health } \\
\text { (1989) }\end{array}$} & \multirow[t]{2}{*}{$\begin{array}{l}\text { I } v . \mathrm{V} \\
\text { Benefits } v . \text { no benefits } \\
\text { Father employed } v \text {. } \\
\quad \text { unemployed }\end{array}$} & $\begin{array}{l}\text { Foods: } \\
\text { Total bread } \\
\text { White bread } \\
\text { Eggs } \\
\text { Total potato } \\
\text { Chips } \\
\text { Baked beans (older children) } \\
\text { Sugar }\end{array}$ & $\begin{array}{l}\text { Foods: } \\
\text { Milk } \\
\text { Carcass meat } \\
\text { Chicken } \\
\text { Citrus fruit } \\
\text { Apples and pears }\end{array}$ \\
\hline & & & & $\begin{array}{l}\text { Nutrients: } \\
\beta \text {-Carotene equivalents } \\
\text { Vitamin C }\end{array}$ \\
\hline
\end{tabular}

PUFA, polyunsaturated fatty acids.

away from home) by income group in families with two adults and two children for a range of foods associated with better health (Ministry of Agriculture, Fisheries and Food, 1996). Food purchases are higher per person per week for families with a high income (group A) compared with those for families from lower-income groups (D and E2), with the exception of poultry. Food purchases are higher in group D (households with an earner who are able to retain Child Benefit over and above the income specified) than in group E2 (low-income families with no earner who are largely dependent on Income Support from which Child Benefit is deducted). For some foods, notably brown and wholewheat bread, total fruit, fresh fruit, and vegetables other than fresh green vegetables and potatoes, the differences between the highest and lowest income groups are over twofold. These differences are reflected in lower intakes of minerals (Fig. 2(a)) and vitamins (Fig. 2(b)). It is worth noting that the differences are attributable to differences in spending and not to poorer spending efficiency in lower-income households: indeed, lower-income households are consistently more efficient (in terms of $\mathrm{g}$ food or nutrients obtained per pence) than higher-income households (Nelson, 1999).

Lower consumption of 'healthy' foods is found in households of different composition (Fig. 3(a-c)). Lone parents on low income, for example, have a lower consumption of fresh green vegetables, total vegetables, and total fruit compared with higher-income lone parents (Ministry of Agriculture, Fisheries and Food, 1998; there are too few lone parents in income group A to be reported in the National Food Survey). They also tend to have a lower consumption 


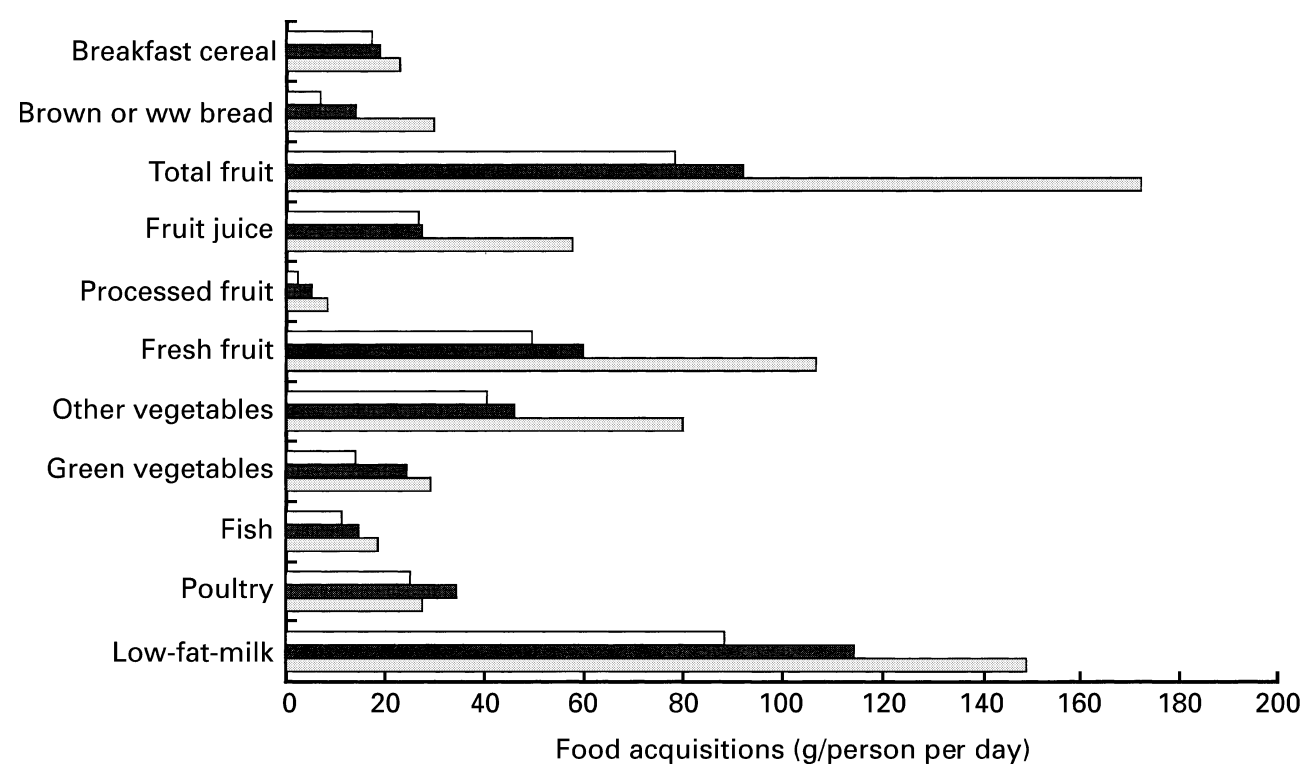

Fig. 1. Food acquisitions (National Food Survey 1995) for households with two adults and one or two children by income group: group A, $\geq £ 570 /$ week $(\square)$ ); group D, <£140/week (earner; - ); group E2, <£140/week (no earner; $\square$ ). ww, Wholewheat. (Data from Ministry of Agriculture, Fisheries and Food, 1996.)

compared with other low-income families with two adults and one or more children. Average consumption levels for these foods in two-parent families fall with each additional child (this is not surprising as children have smaller appetites and lower consumption levels), but for each household type, consumption levels are consistently lower for families on lower incomes (group C or groups D and E2).

Fig. 3(b and c) also show the World Health Organization (1990) recommended levels for vegetable and fruit consumption ( $250 \mathrm{~g}$ vegetables/d or $1750 \mathrm{~g} /$ week, and $200 \mathrm{~g}$ fruit/d or $1400 \mathrm{~g} /$ week respectively). Only for total fruit for group A families with two adults and one or two children is the recommended level achieved. All other income levels and household types fail to meet the recommendations. The failure is most dramatic for those on low incomes, consumption falling in some groups to well below $50 \%$ of the recommended levels.

\section{Lone parents}

Lone parents represent a particularly vulnerable group, since well over $80 \%$ are dependent on Income Support. Dowler \& Calvert (1995) reported on the diets of lone parents and their children. Rather than using income as a measure of deprivation, they looked at aspects of lifestyle or circumstances to identify those who were worst off. Families were classified using a poverty index: those who were long-term unemployed council tenants, had not had a holiday in the previous year and whose benefit was subject to rent or fuel deductions or who used a key meter (a prepaid system more expensive than other forms of payment) were given an index rating equal to 2 ; those who were either unemployed council tenants or whose benefit was subject to rent or fuel deductions or who used a key meter were assigned an index rating equal to 1 ; all other families were given a rating of 0 . Amongst the parents, nutrient intakes (expressed as a percentage of the Department of Health (1991) reference nutrient intake) were consistently lower amongst those with a poverty index of 2 , adequacy often being only half that of those rated 0 , with those rated 1 intermediate. The adequacy of the children's diets was not reported. While to some extent parents claimed to protect their children's diets from the worst effects of poverty: 'I've walked about with holes in my shoes, no winter coat and haven't eaten for three days to look after them... I won't let my kids go without,' the reality was often different: 'I buy apples and bananas every fortnight... It's horrible when she has a banana and then says, "Can I have an apple?" and you've got to stop her because it's got to last.' (It is worth noting that if the first mother's comment accurately reflected her actions, her diet was likely to produce adverse effects on the outcomes of her pregnancies (Barker, 1997), thereby perpetuating the inter-generational associations between low social class and poor health.) Analysis by Dowler \& Calvert (1995) of factors associated with better diets and better dietary variety in the children included having a parent who was older, who looked for 'freshness' when food shopping, who was black, who did not buy food because it was 'cheap' and, of course, who was not poor.

\section{Policy options to improve the diets of children from poor families}

Several recent documents put forward policy options intended to reduce food poverty, either directly (Department of Health, 1996; National Food Alliance, 1998; Nelson, 1999) or indirectly (Acheson, 1998; Parker, 1998; Social Exclusion Unit, 1998). The recommendations do not always relate specifically to the alleviation of food poverty in children, but they can be summarized under three broad headings which highlight ways in which to address children's needs: 

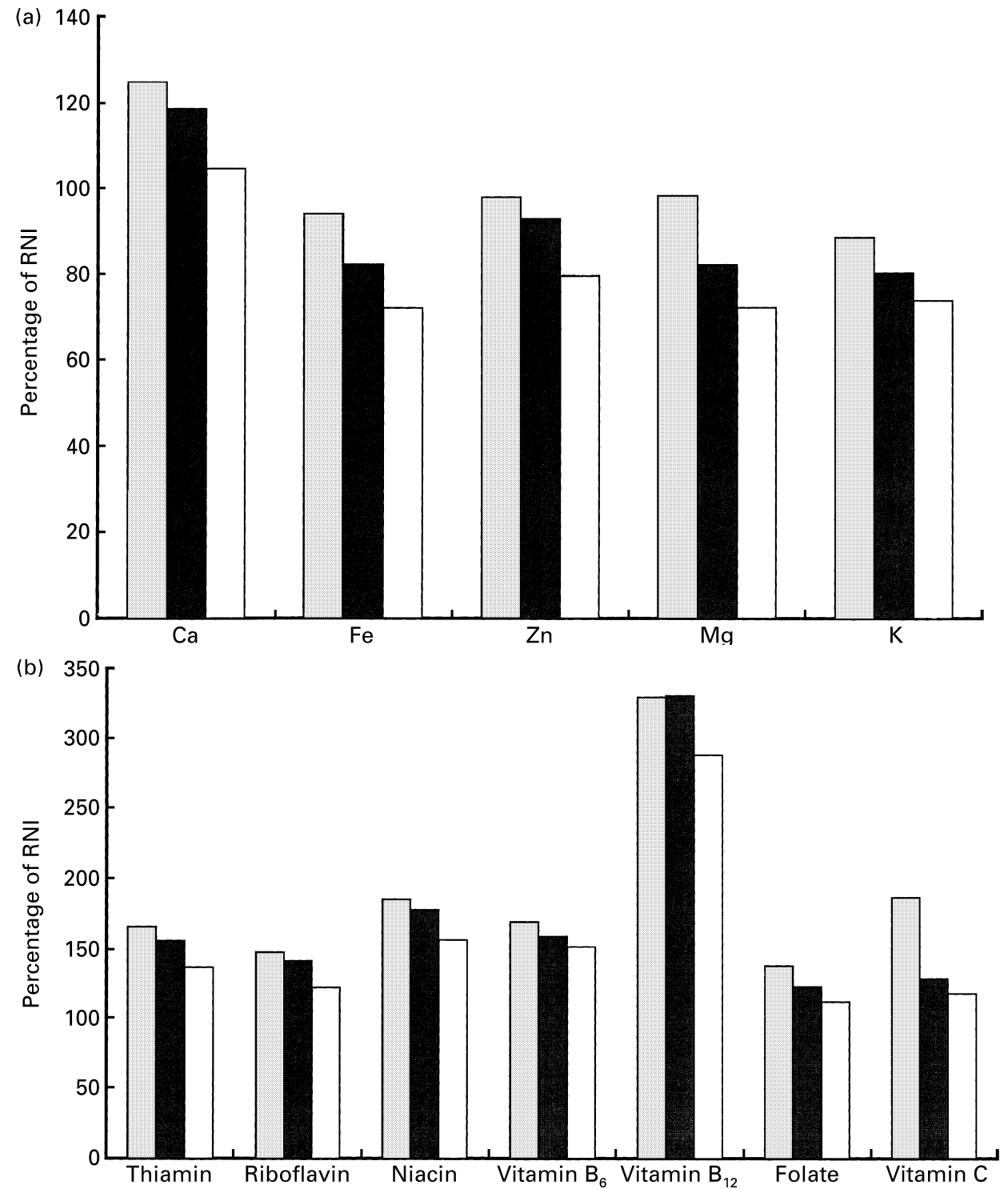

Fig. 2. Dietary adequacy (\% reference nutrient intake (RNI); Department of Health, 1991) for (a) minerals and (b) vitamins (National Food Survey 1995) for households with two adults and one or two children by income group: group $A, \geq £ 570 /$ week ( $\square$ ); group $D,<£ 140 /$ week (earner; $\boldsymbol{\square}$ ); group E2, <£140/week (no earner; $\square$ ). (Data from Ministry of Agriculture, Fisheries and Food, 1996.)

give money to the parents;

feed the children;

improve access to healthy and affordable diets.

\section{Give money to the parents}

Increase Income Support rates. There is ample evidence to show that families with more money to spend on food have better diets. Some individuals may argue that giving more money to poor families does not guarantee that it will be spent on food. Findings from Dobson et al. (1994), however, suggest that food budgets are often squeezed when other aspects of the household budget compete (e.g. to pay a gas bill or buy children's trousers). Taking pressure off the food budget by providing extra money is likely to result in more stable, varied and adequate food purchasing. Moreover, poor families are more efficient than rich families in their purchasing both of the quantity of food and of nutrients (Nelson, 1999). The prejudice that extra money in the budget will be spent on alcohol and cigarettes (rather than food) has no foundation.

'Ring fence' money for food. This policy option has long been the practice in the USA where food stamps are issued. There are clearly some disadvantages to the use of food stamps or vouchers: the limited range of foodstuffs which can be purchased; the restricted participation of food outlets; the reduction in the flexibility of budgeting when competing demands arise; the development of 'black economies' which allow food stamps to be used for non-food purchasing. These disadvantages do not, however, outweigh their primary purpose, which is to ensure the provision of a core of staple dietary items at affordable prices. Vouchers for milk, infant formulas and vitamins have been used in the UK for over 50 years (and more recently for food for refugee families from Eastern Europe), but there have been no schemes to evaluate their extension to other foods. 

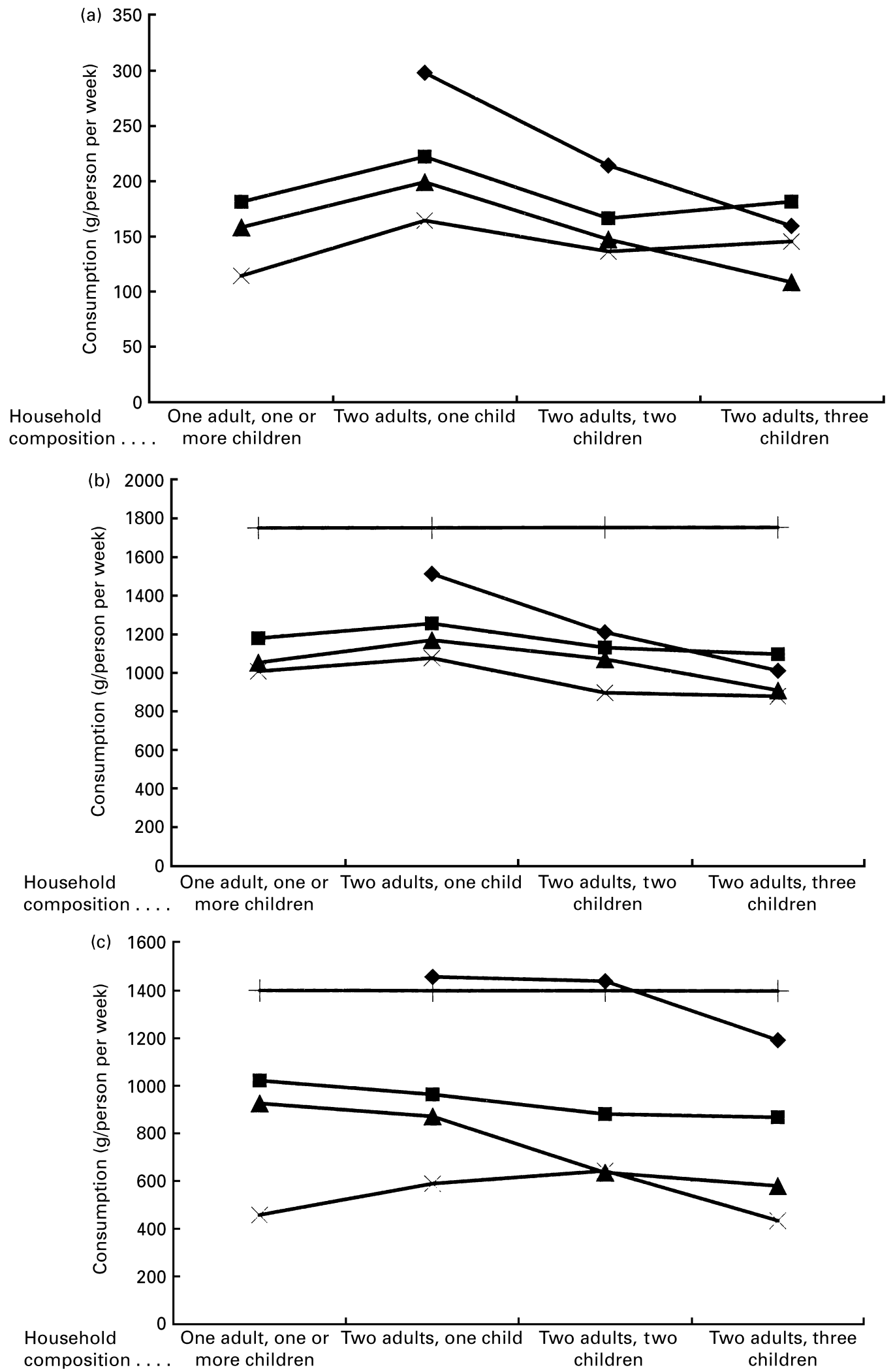

Fig. 3. (a) Fresh green vegetable consumption, (b) total vegetable consumption and (c) total fruit consumption by income and household composition (National Food Survey 1997). ( $\bullet$ ), Group A $\geq £ 610 /$ week; (田), group B $\geq £ 310<£ 610 /$ week; $(\mathbf{\Delta})$, group $C \geq £ 150<£ 310 /$ week; (X), groups D and E2, <£150/week; (一), World Health Organization (1990) recommended intake (Data from Ministry of Agriculture, Fisheries and Food, 1998.) 
Increase Child Benefit, particularly for those on Income Support. Recent increases in Child Benefit rates have been welcomed by the poverty lobby. These increases are not reflected in Income Support rates, however, as Child Benefit is deducted from Income Support payments before payment is made, so families without an earner are no better off when Child Benefit rates increase.

Reduce tax for the poorest. Bottom-rate taxes are currently $20 \%$. Further reduction to $10 \%$ or $0 \%$ for the lowest earners would cost the exchequer very little but would provide real additional income for those at the bottom of the income ladder.

Use budget standards to inform tax and benefit levels. At no point in the formulation of Income Support, Child Benefit or Working Family Tax Credit rates does the Government define a level of expenditure which is commensurate with good health (physiological, psychological and social). Minimum income standards are used in other countries (Viet Wilson, 1998). The Family Budget Unit has published minimum income standards for families with young children (Parker, 1998). These standards include food budget standards which have been set at a 'low cost but acceptable' (LCA) level. LCA food budget standards represent a basket of goods which is socially and culturally acceptable. They are based on 1992-6 National Food Survey patterns of home food purchasing for defined household types at a level of income commensurate with the concept of LCA (Ministry of Agriculture, Fisheries and Food, 1993, 1994, 1995, 1996, 1997). The National Food Survey data are supplemented by information from the 1995-6 Family Expenditure Survey (Office for National Statistics, 1997) concerning expenditure on food purchased and eaten outside the home. Guidelines for healthy eating from the Department of Health (1991) and the Health Education Authority $(1996 a, b, 1997)$ are used to adjust the food baskets.

Table 2 shows summary food budgets for families with two adults and two children (boy aged 10 years and girl aged 4 years) and a lone mother (a lone father would need to spend approximately $£ 6.00$ per week more than the lone mother to satisfy his nutritional needs, particularly for energy) with two children of the same ages (Nelson et al. 1998). These budgets illustrate the amounts that need to be spent to obtain an affordable and healthy diet. They are

Table 2. Food and alcohol costs at low cost but acceptable level, January 1998 prices

\begin{tabular}{lcc}
\hline & $\begin{array}{c}\text { Couple with two } \\
\text { children }\end{array}$ & $\begin{array}{c}\text { Lone mother with } \\
\text { two children }\end{array}$ \\
\hline $\begin{array}{l}\text { Total food, home budget } \\
\text { Foods purchased and eaten } \\
\text { away from home }\end{array}$ & $£ 49.12$ & $£ 32.66$ \\
$£ 10.04$ & $£ 4.81$ \\
$\begin{array}{l}\text { Total budget, food only: } \\
\text { If no alcohol included in the } \\
\quad \text { diet }\end{array}$ & $£ 59.16$ & $£ 37.47$ \\
$\quad \begin{array}{l}\text { If alcohol included in the } \\
\quad \text { diet }\end{array}$ & $£ 57.32$ & $£ 36.78$ \\
$\begin{array}{l}\text { Alcohol } \\
\text { Total budget, food plus } \\
\text { alcohol }\end{array}$ & $£ 8.62$ & $£ 4.01$ \\
\hline
\end{tabular}

supported by specific baskets of foods and menus reflecting this level of expenditure. Alcohol is not a dietary essential, but may have important benefits relating to social inclusion (being able to enjoy a drink with a friend or partner). The budgets have therefore been costed with and without alcohol. The baskets were tested in families who bought similar foods at these levels of expenditure. They found their food consumption to be more than adequate, enjoyable and an improvement on their previous diet.

Orshansky (1965) proposed that a useful 'poverty line' was one which assessed the percentage of the household budget which needed to be spent on food. She proposed that a family which had to spend more than one-third of its net income on food (after taxes and housing costs) could be regarded as living in poverty, as spending on food at that level would be unlikely to leave adequate funds for other aspects of living such as heating and clothing. Citro \& Michael (1995) have reviewed this value, and suggest that $30 \%$ expenditure on food after tax and housing costs is an appropriate modern 'poverty line'. Fig. 4 shows the LCA level of expenditure as a percentage of Income Support. Families with two adults and two young children would have to spend between 45 and $51 \%$ of their Income Support to achieve LCA level. Lone mothers with two young children would need to spend between 34 and $37 \%$ of their Income Support on food. A lone father would have to spend between 41 and $44 \%$. These values are substantially above the $30 \%$ poverty line suggested by Citro \& Michael (1995). According to this model, families with young children living on Income Support can be regarded as living in poverty.

The usefulness (and validity) of food budget standards as a proxy for dietary adequacy can be illustrated by comparing the relationship between food expenditure and health. Nelson \& Naismith (1979) found that children aged 1-12 years living in 'at-risk' families with low expenditure on food were shorter than children living in families spending more on food and they had more ill health. ('At risk' was defined as living in a lone-parent family, having three or more siblings under 17 years of age, living in a family whose only income was from Supplementary Benefit (now Income Support), or living in overcrowded conditions (more

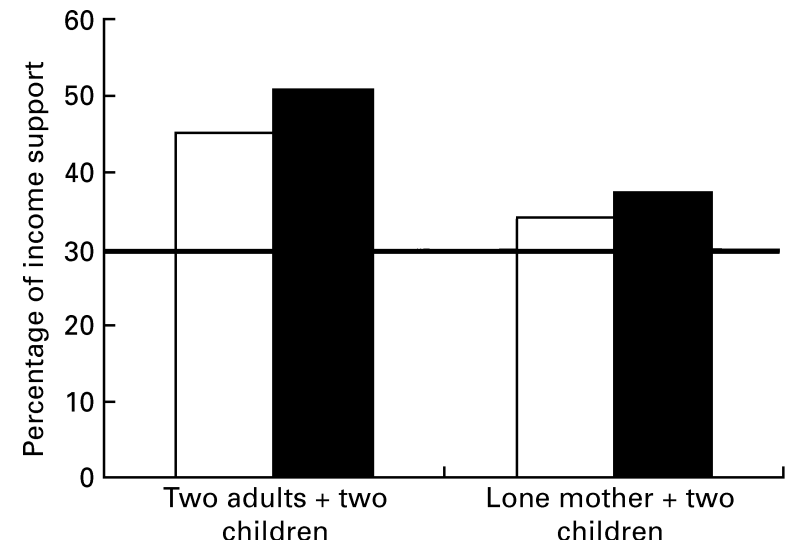

Fig. 4. Cost of food (with or without alcohol) at Low Cost but Acceptable level as a percentage of Income Support (January 1998 prices and benefit rates). ( $\square$ ), Percentage expenditure, no alcohol; $(\boldsymbol{\square})$, percentage expenditure, with alcohol; (-), 'poverty line' (Citro \& Michael, 1995). 
than 1.5 persons per room.)) The study was repeated in the summer of 1998 in a similar cross-section of families. The mean centile for height of children living in families spending below the LCA level on food was the 42nd centile. In contrast, children living in families spending above the LCA level had an average height on the 59th centile. Recurrent diarrhoea was five times more common amongst the children in families spending below the LCA level on food. It could be argued that these findings simply reflect other aspects of family life associated with poor growth and ill health (and financial mismanagement). However, when mother's height, child's birth weight and mother's education were taken into account, the amount spent on food remained as the most powerful predictor of child height.

The short-term gains of giving food or money to the poorest mothers and children has been illustrated in the USA by the Women, Infants and Children scheme. For every $\$ 1.00$ spent in the programme it is estimated that \$1.92-4.21 were saved on welfare health costs (Cain, 1997). For every woman receiving Women, Infants and Children support during pregnancy, welfare health costs are reckoned to fall by between $\$ 376$ and $\$ 753$. Amongst children participating in the Women, Infants and Children programme anaemia is reduced by two-thirds. These short-term gains will of course be reflected in long-term benefits relating to educational achievement and health in adulthood.

\section{Feed the children}

Giving money to the parents (either directly in terms of cash or indirectly in terms of related benefits or services) is clearly a powerful way to improve the nutritional health of children. However, there are arguments for feeding children directly, as there will always be some families in which the resources are not necessarily distributed in favour of the children.

Reinstate school meals for families receiving Working Family Tax Credit. Children living in families receiving Income Support are entitled to free school meals. Before 1988 children living in families receiving Family Credit were also entitled to free school meals. The change in the law meant that families who moved from Income Support to low-paid work were worse off financially as a result of finding employment. The Free School Meals campaign currently being coordinated by the Child Poverty Action Group (London) is promoting a reversal of this legislation to ensure that the maximum number of children in low-income families receive an entitlement to free school meals.

School fruit. For many years, children were entitled to receive free milk at school. Again, changes in legislation (School Milk Campaign, 1996) resulted in the loss of this benefit. There are arguments in favour of reversing this policy in terms of improved bone health in children. However, recent developments in the understanding of the aetiology of heart disease and some types of cancer suggest that improvements in antioxidant status would be of benefit in reducing the risks of these chronic diseases in all children, especially those from low-income households. Tons of fruit are destroyed each year because of surpluses produced within the European Community (Lobstein 1999a,b). There is a strong argument for distributing rather than destroying this produce.

Breakfast clubs at schools and nurseries. The proliferation of breakfast and after-school clubs provides child care for parents who may be working outside school hours. Many of these clubs offer food. Although they are encouraged by Government, and start-up money is sometimes available from local authorities, their long-term financing is often precarious (McGlone et al. 1999). A better option would be more secure provision.

Guidelines for feeding at school. Before 1980 all schools were required to provide school lunches which achieve a specified nutrient content. Legislation passed in 1980 removed those requirements. Guidelines on school feeding were published by the Caroline Walker Trust (1996), and in 1998 the Government invited comment on proposals for new guidelines. These new guidelines are intended to relate to all food provided at school, not just lunchtime meals.

\section{Improve access to a healthy and affordable diet}

One of the key recommendations of the Acheson (1998) report is to ensure that all individuals in the population have access to a healthy and affordable food supply. This proposal means that when supermarkets are located on the outskirts of towns or away from large housing estates, families without access to a car are not put at a disadvantage, but have access to cheap, regular and reliable public transport. The first task, therefore, may be the identification of 'food deserts' in which access to cheap, varied and nutritious foods is not available. Food deserts can exist even in inner city areas as a result of poor shop siting and transport provision. Another strategy is to help small shops in specified areas (e.g. those with a high proportion of families on low income, low car ownership, or isolated villages) to maintain their competitiveness by reducing local authority rates and property taxes. A further strategy would be to encourage supermarkets to improve the range of economy-line foods on offer and to ensure that low-cost fruits and vegetables are regularly available.

\section{Conclusions}

The evidence presented in the present paper shows that poor children are nutritionally disadvantaged. Poverty is endemic in the UK, and undernutrition is widespread amongst children living in families on low income. This undernutrition manifests itself in both the short term (e.g. poor growth, reduced immune status, poorer cognitive function, poorer educational outcomes) and the long term (e.g. increased risks of chronic disease in adulthood, poverty relating to chronic ill health). Undernutrition is a consequence of inadequate spending on food because of limited money to spend, and poor access by many lowincome families to a healthy and affordable food supply. The problem is not confined to the UK, but is manifest in most developed countries (Riches, 1995).

Acheson (1998) has called for all Government legislation and policy options relating to health to be considered in light of their impact on health inequalities. This recommendation 
should be extended to include consideration of the specific impact on the nutritional health of children.

\section{References}

Acheson D (editor) (1998) Independent Inquiry into Inequalities in Health. London: The Stationery Office.

Barker DJ (1997) Maternal nutrition, fetal nutrition, and disease in later life. Nutrition 13, 807-813.

Burney P (1995) The origins of obstructive airways disease. A role for diet? American Journal of Respiratory and Critical Care Medicine 151, 1292-1293.

Cain AW (1997) Pregnant mothers and their young children - the WIC Program, p. 356. In Nutrition Policy in Public Health, [F Bonner editor] New York: Springer Publishing.

Caroline Walker Trust (1996) Nutritional Guidelines for School Meals. London: Caroline Walker Trust.

Citro CC \& Michael RT (editors) (1995) Measuring Poverty: A New Approach, pp. 108-116. Washington, DC: National Academy Press.

Dallison J \& Lobstein T (1995) Poor Expectations. London: Maternity Alliance.

Dennehy A, Smith L \& Harker P (1997) Not To Be Ignored. Young People, Poverty and Health. London: Child Poverty Action Group.

Department of Health (1989) The Diets of British Schoolchildren. Report on Health and Social Subjects no. 36. London: H.M. Stationery Office.

Department of Health (1991) Dietary Reference Values for Food Energy and Nutrients for the United Kingdom. Report on Health and Social Subjects no. 41. London: H.M. Stationery Office.

Department of Health (1996) Low Income, Food, Nutrition and Health: Strategies for Improvement. A Report by the Low Income Project Team for the Nutrition Task Force. London: Department of Health.

Dobson B, Beardsworth A, Keil T \& Walker R (1994) Diet, Choice and Poverty: Social, Cultural and Nutritional Aspects of Food Consumption among Low Income Families. London: Family Policy Studies Centre.

Dowler E \& Calvert C (1995) Nutrition and Diet in Lone-parent Families in London. London: Family Policy Studies Centre.

Government Statistical Service (1996) Households Below Average Income: A Statistical Analysis 1979-1993/94. London: Department of Social Security.

Gregory JR, Collins DL, Davies PSW, Hughes JM \& Clarke PC (1995) National Diet and Nutrition Survey: Children Aged 1 1/2 to $4^{1} / 2$. London: H.M. Stationery Office.

Health Education Authority (1996a) Enjoy Healthy Eating. London: Health Education Authority.

Health Education Authority (1996b) Think About Drink. London: Health Education Authority.

Health Education Authority (1997) Enjoy Fruit and Veg (With Recipes). London: Health Education Authority.

James WPT, Nelson M, Ralph A \& Leather S (1997) The contribution of nutrition to inequalities in health. British Medical Journal 314, 1545-1549.

Lobstein T (1999a) Are the EU's agriculture policies undermining public health? Prospects for Public Health Seminar. Brussels: EU Parliament

Lobstein T (1999b) Is fruit for charities being dumped illegally? Food Magazine 42,17.
Lucas A, Morley R, Cole TJ, Lister G \& Leeson-Payne C (1992) Breast milk and subsequent intelligence quotient in children born preterm. Lancet 339, 261-264.

McGlone P, Dobson B, Dowler E \& Nelson M (1999) Food Projects and How They Work. York: Joseph Rowntree Foundation.

Martin J \& White A (1988) Infant feeding 1985. London: H.M. Stationery Office.

Mills A \& Tyler H (1992) Food and Nutrient Intakes of British Infants aged 6-12 months. London: H.M. Stationery Office.

Ministry of Agriculture, Fisheries and Food (1993) National Food Survey 1992. London: H.M. Stationery Office.

Ministry of Agriculture, Fisheries and Food (1994) National Food Survey 1993. London: H.M. Stationery Office.

Ministry of Agriculture, Fisheries and Food (1995) National Food Survey 1994. London: H.M. Stationery Office.

Ministry of Agriculture, Fisheries and Food (1996) National Food Survey 1995. London: H.M. Stationery Office.

Ministry of Agriculture, Fisheries and Food (1997) National Food Survey 1996. London: H.M. Stationery Office.

Ministry of Agriculture, Fisheries and Food (1998) National Food Survey 1997. London: The Stationery Office.

National Food Alliance (1998) Food Poverty: What are the Policy Options? London: National Food Alliance.

Nelson M \& Naismith DJ (1979) The nutritional status of poor children living in London. Journal of Human Nutrition 33, 3345.

Nelson M, Bakaliou F \& Trivedi A (1994) Iron deficiency anaemia and physical performance in adolescent girls from different ethnic backgrounds. British Journal of Nutrition 72, 427-433.

Nelson M, Dallison J \& Paterakis S (1998) Low cost but acceptable food budget standards. In Low Cost but Acceptable: A Minimum Income Standard for the UK: Families with Young Children, pp. 18-32 [H Parker, editor]. Bristol: Policy Press.

Nelson M (1999) Nutrition and health inequalities. In Inequalities in Health, pp. 118-137 [D Gordon, M Shaw, D Dorling and G Davey Smith, editors]. Bristol: Policy Press.

Office For National Statistics (1997) Family Spending 1992-1996. London: The Stationery Office.

Orshansky M (1965) Counting the poor. Another look at the poverty profile. Social Security Bulletin 28, 3-29.

Parker H (editor) (1998) Low Cost but Acceptable: A Minimum Income Standard for the UK: Families with Young Children. Bristol: Policy Press.

Riches G (editor) (1997) First World Hunger. Basingstoke, Hants.: MacMillan Press.

Ruxton CH \& Kirk TR (1996) Relationships between social class, nutrient intake and dietary patterns in Edinburgh schoolchildren. International Journal of Food Science and Nutrition 47, 341-349.

School Milk Campaign (1996) The Hunger Within. Stafford: School Milk Campaign.

Social Exclusion Unit (1998) Bringing Britain Together: a national strategy for neighbourhood renewal. September 1998. http://www.open.gov.uk/co/seu/bbt.pdf.

Viet-Wilson J (1998) Setting Adequacy Standards. Bristol: Policy Press.

Wenlock RW, Disselduff MM, Skinner RK \& Knight I (1986) The Diets of British Schoolchildren, Preliminary Report of a Nutritional Analysis of a Nationwide Dietary Survey of British Schoolchildren. London: Department of Health and Social Security.

World Health Organization (1990) Diet, Nutrition, and Prevention of Chronic Diseases. Report of a WHO Study Group. Technical Report Series no. 797. Geneva: WHO. 